Tropical Journal of Pharmaceutical Research November 2015; 14 (11): 2031-2039

ISSN: $1596-5996$ (print); 1596-9827 (electronic)

(c) Pharmacotherapy Group, Faculty of Pharmacy, University of Benin, Benin City, 300001 Nigeria.

All rights reserved.

Available online at http://www.tjpr.org

Original Research Article

http://dx.doi.org/10.4314/tjpr.v14i11.12

\title{
Anticonvulsant, Antimicrobial and Cytotoxic Activities of Berberis calliobotrys Aitch ex Koehne (Berberidaceae)
}

\author{
Shahid Rasool ${ }^{1,2 \star}$, Farrukh Zia Khan ${ }^{1}$, Saeed ul Hassan1, Mobasher Ahmed", \\ Mansoor Ahmed ${ }^{3}$ and Rasool Bakhsh Tareen ${ }^{4}$ \\ ${ }^{1}$ University College of Pharmacy, University of the Punjab, Lahore-54000, ${ }^{2}$ Faculty of Pharmacy, University of Sargodha, \\ Sargodha-44100, ${ }^{3}$ Faculty of Pharmacy, University of Karachi, Karachi-75500, ${ }^{4}$ Department of Botany, University of \\ Baluchistan, Quetta, Pakistan
}

*For correspondence: Email: shahid_rph@hotmail.com; Tel: 00923004799126

Received: 20 June 2015

Revised accepted: 2 October 2015

\begin{abstract}
Purpose: To evaluate the anticonvulsant, antimicrobial and cytotoxic activities of Berberis calliobotrys. Methods: The powdered plant material (10 kg) was extracted thrice with methanol $(3 \times 12 \mathrm{~L})$ by dipping for seven days. The methanol extract was concentrated to dryness under reduced pressure, and then successively fractionated with solvents of different polarity, including $n$-hexane, chloroform, ethyl acetate and $n$-butanol. The anticonvulsant effect of the extract and fractions (at oral doses 500 and $1000 \mathrm{mg} / \mathrm{kg}$ ) was studied against picrotoxin-, pentylenetetrazole (PTZ)- and strychnine-induced seizures in Swiss albino mice of either sex divided into 12 groups $(n=6)$. Diazepam was used as standard drug. Antimicrobial activity of the extract against Bacillus subtilis, Pseudomonas aeruginosa, Staphylococcus aureus as well as against Candida albicans, Penicillium notatum was conducted by disc diffusion method and minimum inhibitory concentration (MIC). Cytotoxicity of the extract/fractions was analyzed by haemolytic method while the phenolic compounds present in the ethyl acetate fraction of the plant were determined by high performance liquid chromatography (HPLC).

Results: The extract and its ethyl acetate and n-butanol fractions showed maximum response against drug-induced convulsions and provided $100 \%$ protection to animals at both doses. They also showed zones of inhibition of $27.00 \pm 2.51$, and $22.00 \pm 2.51 \mathrm{~mm}$ against all bacterial and fungal strains, respectively, especially Staphylococcus aureus. The methanol extract and ethyl acetate fraction also showed high MIC against all bacterial and fungal strains. Cytotoxicity data from hemolytic assay indicate that the extract/fractions are safe. The highest amount of phenolic found was chlorogenic acid (84.44 \pm $0.06 \mathrm{ppm})$.

Conclusion: The plant is thus a potential source of new lead compounds for the development of new clinically effective anticonvulsant and antimicrobial compounds.
\end{abstract}

Keywords: Berberis calliobotrys, Anticonvulsant, Antimicrobial, Haemolytic, Phenolics, Chlorogenic acid

Tropical Journal of Pharmaceutical Research is indexed by Science Citation Index (SciSearch), Scopus, International Pharmaceutical Abstract, Chemical Abstracts, Embase, Index Copernicus, EBSCO, African Index Medicus, JournalSeek, Journal Citation Reports/Science Edition, Directory of Open Access Journals (DOAJ), African Journal Online, Bioline International, Open-J-Gate and Pharmacy Abstracts

\section{INTRODUCTION}

Berberis calliobotrys Aitch. ex Koehne (Berberidaceae), commonly known as Choweng, is an important medicinal plant mostly found in
North Temperate regions, tropical mountains and South America [1].

This plant is used in various systems of medicines for treating different types of ailments. The fruits of the plant are crushed and boiled in 
water and used for fever. A paste is prepared from the bark of the rhizome by mixing with equal weight of black pepper and butter and is applied locally for backache. Decoction of bark is used as a gargle for pharyngitis. This plant is also used in some liver infections and intestinal colitis [2].

An aporphine - benzylisquinoline alkaloid, khyberine has been reported in Berberis calliobotrys ( $B$. calliobotrys) in about one part per million. A complete scheme for the biogenesis of khyberine was presented which described that it was formed by the condensation of two coclaurine units $[3,4]$.

Western medicines became the main system of health care, but different communities still continue to benefit from the folk knowledge of the use of plants as medicines. Unfortunately, most of this knowledge base has never been documented and thus threatened to disappear with the rapid demographic changes. The extensive folklore uses of $B$. calliobotrys for the treatment of different diseases have led to ensure its pharmacological activities. In this paper, the anticonvulsant, antimicrobial and in vitro cytotoxic effects of this plant species were evaluated which might be utilized to standardize the plant for therapeutic purposes. The plant was also estimated for the presence of phenolic constituents by HPLC which might be responsible for these pharmacological activities.

\section{EXPERIMENTAL}

\section{Collection and preparation of plant material}

B. calliobotrys was collected from the hilly areas of Quetta, Balochistan, Pakistan. The specimen was further identified and authenticated by taxonomists, Prof Dr Rasool Bakhsh Tareen, Department of Botany, University of Baluchistan, Quetta and Prof Dr. Zaheer Ahmad Khan, Department of Botany, GC University, Lahore, Pakistan. Voucher specimen number 1912 was deposited in the Sultan Ayoub Herbarium, GC University Lahore for further reference. Stems and branches of plant were spread on laboratory tables and dried under the shade for seven days at room temperature. The plant was pulverized prior to use by using an electric mill. The powdered plant material $(10 \mathrm{~kg})$ was extracted thrice with methanol $(3 \times 12 \mathrm{~L})$ by dipping for seven days. The methanol extract was concentrated to dryness under reduced pressure using a rotary evaporator (Heidolph, model Laborata 4000, Schwabach, Germany). The methanol extract was further fractioned using a successive solvent extraction method with different polarity based solvents such as nhexane, chloroform, ethyl acetate and n-butanol. After fractionation samples were concentrated to dryness under reduced pressure and stored in a refrigerator at $4{ }^{\circ} \mathrm{C}$, until used for analysis [5].

\section{Preparation of test microorganisms}

The pathogenic bacterial strains, namely, Bacillus subtilis (ATCC 6633) Pseudomonas aeruginosa (ATCC 27853) and Staphylococcus aureus (ATCC 12228) and fungal strains namely Candida albicans (ATCC 18804) and Penicillium notatum (ATCC 11709) were obtained from Musaji Adam and Sons, Rawalpindi, Pakistan and used for antibacterial and antifungal activity respectively. All the microbial strains were transferred to nutrient agar slants, then shifted to nutrient broth and stored at $4{ }^{\circ} \mathrm{C}$ until used.

\section{Animals}

Healthy lab bred adult male/female Swiss albino mice (22-30 gm body weight) were used for experimental purposes. The animals were housed in metabolic animal cages and maintained at controlled room temperature of 25 $\pm 10{ }^{\circ} \mathrm{C}$. All the animals had free access to food and water ad libitum. Treatment of experimental animals was performed according to protocols approved by the animal ethical committee of University College of Pharmacy, University of the Punjab, Lahore, Pakistan (vide reference no. 2009). The protocols, ethics and regulations governing the care and use of experimental animals in "Principles of laboratory animal care" were followed [6].

\section{Phytochemical screening}

Different chemical tests were conducted, using reported methods, to check out the presence of various phytoconstituents from methanol extract and its fractions [7-9].

\section{Evaluation of anticonvulsant activity}

The anticonvulsant effect of plant crude extract and its various fractions was performed according to method with minor modifications as described by Swinyard et al [10]. Swiss albino mice of either sex were randomly divided into 12 groups of 6 mice each: (1) negative control group with normal saline and Tween $(10 \mathrm{~mL} / \mathrm{kg})$; (2) positive control group with diazepam $(4 \mathrm{mg} / \mathrm{kg})$; extract-treated groups (500 and $1000 \mathrm{mg} / \mathrm{kg}$, as groups 3 and 4 , respectively); n-butanol fractiontreated groups (500 and $1000 \mathrm{mg} / \mathrm{kg}$, as groups 5 and 6respectively); ethyl acetate fraction- 
treated groups (500 and $1000 \mathrm{mg} / \mathrm{kg}$, as groups 7 and 8 respectively); chloroform fraction-treated groups (500 and $1000 \mathrm{mg} / \mathrm{kg}$, as groups 9 and 10, respectively); and n-hexane fraction-treated groups (500 and $1000 \mathrm{mg} / \mathrm{kg}$, as groups 11 and 12 , respectively). All the animals were fasted for $24 \mathrm{~h}$ before the start of the experiment, but were granted free access to water. Treatment was oral, 30 min prior to administration of convulsioninducing drugs, i.e., PTZ (80 mg/kg), strychnine $(2.5 \mathrm{mg} / \mathrm{kg})$ and picrotoxin $(10 \mathrm{mg} / \mathrm{kg})$ intraperitonally. The animals were placed individually in plastic boxes and observed immediately for a period of 30 min and after $24 \mathrm{~h}$. The onset time of hind limb tonic extensions (HLTEs), duration of tonic convulsions and percent against mortality protection (mortality protection) were recorded.

\section{Determination of antimicrobial activity}

The antimicrobial assay for plant extract and fractions against different bacterial and fungal strains was conducted by disc diffusion method and minimum inhibitory concentration (MIC) [11].

\section{Disc diffusion}

Filter paper discs prepared from Whatman no. 1 having a diameter of 6 millimetres were loaded with $2 \mathrm{mg}$ of dried extract per disc. Discs were dried and sterilized by using autoclave at $121^{\circ} \mathrm{C}$ and 15 pound/sq. inch pressure for $15 \mathrm{~min}$ [12] Thereafter, $0.1 \mathrm{~mL}$ of culture $\left(3 \times 10^{8}\right.$ cells $\left./ \mathrm{ml}\right)$ according to McFarland standard was spread over Muller Hinton agar medium for antibacterial assay and Sabouraud dextrose liquid medium for antifungal assay. Filter paper discs were placed over the surface of the media with flamed forceps pressed gently to ensure contact. The plates were placed for $2 \mathrm{~h}$ in the refrigerator to ensure pre diffusion of the extract into the surface of the agar. The plates were incubated at $37^{\circ} \mathrm{C}$ for $24 \mathrm{~h}$ and at $28{ }^{\circ} \mathrm{C}$ for $48 \mathrm{~h}$ against bacterial and fungal strains respectively. Commercial antibiotic ciprofloxacin and antifungal fluconazole were used as positive control. After the incubation period, antimicrobial activity was determined by measuring the zone of inhibition $(\mathrm{mm})$, i.e., the diameter of the paper disc plus the diameter of the zone [11,12].

\section{Minimum inhibitory concentration (MIC)}

Broth micro-dilution method was used for the determination of MIC with some modifications of the procedure as adopted by Sarker et al [13]. For this purpose, sterilized 96-microtitre well plates were used. A stock solution of methanol extract and all the fractions was prepared up to
$20 \mathrm{mg} / \mathrm{mL}$. From the stock solution, a volume of $50 \mu \mathrm{L}$ of extract and all fractions was added into the first well of the plate. A volume of $50 \mu \mathrm{L}$ of nutrient broth was added in the first well of the plate. After mixing, $50 \mu \mathrm{L}$ of mixture from the first well was transferred to the next well and mixed with $50 \mu \mathrm{L}$ of broth. Similarly, this serial dilution procedure was repeated up to the last well and then $50 \mu \mathrm{L}$ was discarded. The tip of micropipette was discarded after single use. Then, $10 \mu \mathrm{L}$ of resazurin indicator solution (270 $\mathrm{mg}$ in $40 \mathrm{ml}$ sterilized distilled water) was added to each well. Finally, $10 \mu \mathrm{L}$ of inoculum (microorganism suspension) was added to all wells except the last well, which was taken as negative control (extract and medium). Positive control for bacterial growth was also included without extract and medium. The plates were incubated at $37^{\circ} \mathrm{C}$ for $24 \mathrm{~h}$ for bacterial and at $28^{\circ} \mathrm{C}$ for $48 \mathrm{~h}$ for fungal strains. After incubation, the change in colour was observed and well numbers were noted. A colour change from purple to pink was considered as positive. The lowest concentration at which colour change occurred was taken as MIC value.

\section{Evaluation of in vitro cytotoxic activity}

The cytotoxicity of the plant crude extract and its subsequent fractions was analyzed by the haemolytic method as described by Sharma and Aslam with minor modifications [14,15]. A solution of plant extract and each fraction was prepared at a concentration of $1 \mathrm{mg} / \mathrm{ml}$ in DMSO (dimethyl sulfoxide) solution. A volume of $3 \mathrm{~mL}$ of heparinized human blood (freshly obtained) was poured into $15 \mathrm{~mL}$ polystyrene tube and centrifuged for $5 \mathrm{~min}$. The supernatant obtained was poured off and RBCs were washed with 5 $\mathrm{mL}$ of chilled $\left(4^{\circ} \mathrm{C}\right)$ sterile isotonic phosphatebuffered saline (PBS) solution thrice and its $\mathrm{pH}$ is adjusted to 7.4. The cells were then counted on a haemocytometer. The erythrocyte count was maintained to $7.068 \times 10^{8}$ cells $/ \mathrm{mL}$ for each test. An aliquot of $20 \mu \mathrm{L}$ of plant extract and fractions was taken in $2.0 \mathrm{~mL}$ eppendorff's tubes aseptically and $180 \mu \mathrm{L}$ of diluted RBC suspension was added to them. $0.1 \%$ Triton $X$ 100 was used as positive control and PBS as negative control. The samples were incubated at $37^{\circ} \mathrm{C}$ for $35 \mathrm{~min}$. After incubation the tubes were immediately placed on ice for $5 \mathrm{~min}$ and then centrifuged for $5 \mathrm{~min}$. $100 \mu \mathrm{L}$ of supernatant obtained after centrifugation was diluted with 900 $\mu \mathrm{L}$ of chilled PBS solution in eppendorff's tubes. The tubes were then maintained on water ice. After this, $200 \mu \mathrm{L}$ mixture from each tube was transferred in 96 will microtitre plates. Three replicates were taken, including one positive and one negative. Absorbance was measured at 576 
nm using BioTek, $\mu$ CuantTM instrument (BioTeck, Winooski, VT, USA). The \% lysis of RBCs was calculated as in Eq 1.

RBC lysis $(\%)=(\mathrm{As} / \mathrm{At}) 100$

where As and At are the absorbance of sample and triton X-100, respectively

\section{HPLC analysis}

Phenolic compounds present in the ethyl acetate fraction of the plant were estimated by HPLC using a procedure with some modification as mentioned by Sultana [16].

The sample for HPLC analysis was prepared by mixing small amounts of plant ethyl acetate fraction in $5 \mathrm{ml}$ of distilled water. Thereafter, 12 $\mathrm{mL}$ of methanol was added to it. After shaking 6 $\mathrm{mL}$ of distilled water was added and left for 5 min. Finally $10 \mathrm{~mL}$ of $15 \mathrm{M} \mathrm{HCl}$ was added to it and kept in oven at $90{ }^{\circ} \mathrm{C}$ for $2 \mathrm{~h}$. The solution was filtered using syringe filter and analyzed for the presence of phenolics.

The analysis of phenolics was performed by using HPLC (model LC-10AT, Shimadzu, Japan) equipped with two LC-10 AS pumps, SCL-10A system control unit, Rheodyne injector, CTO-10A column oven, SPD-10AV, UV-VIS detector and data acquisition class CSW32 software. The 20 $\mu \mathrm{L}$ volume of the filtered sample was injected into an analytical column (Shim-Pak CLC-ODS, $25 \mathrm{~cm} \times 4.6 \mathrm{~mm}, 5 \mu \mathrm{m})$. The mobile phase used was gradient; (a) water: Acetic acid 94: 6, (b) Acetonitrile $100 \%$. The detection was carried out at $280 \mathrm{~nm}$. The identification was made by external standard methods by comparing with the known standard used in the same conditions.

\section{Statistical analysis}

The results are presented as mean \pm SEM. Statistical significance between the groups was analyzed by analysis of variance (ANOVA) followed by Dunnett's multiple comparison tests. $P<0.05$ was considered as significant.

\section{RESULTS}

\section{Phytochemical profile}

The qualitative phytochemical analysis showed the occurrence of different chemical constituents like alkaloids, glycosides, tannins, saponins, terpenoids, fats, phenols and flavonoids in methanol extract and its various fractions.

\section{Anticonvulsant activity}

The results of PTZ induced convulsions are depicted in Figure 1. The methanol extract and $n$ butanol fraction of $B$. calliobotrys showed maximum protection (100\%) to the animals against PTZ-induced convulsions at both doses. However, at the dose of $1000 \mathrm{mg} / \mathrm{kg}$ they provided result compared with the standard drug diazepam. The $n$-hexane fraction at a dose of $500 \mathrm{mg} / \mathrm{kg}$ did not produce any significant delay in the onset of convulsions and also duration of convulsions however, some protection was provided to animals against death.

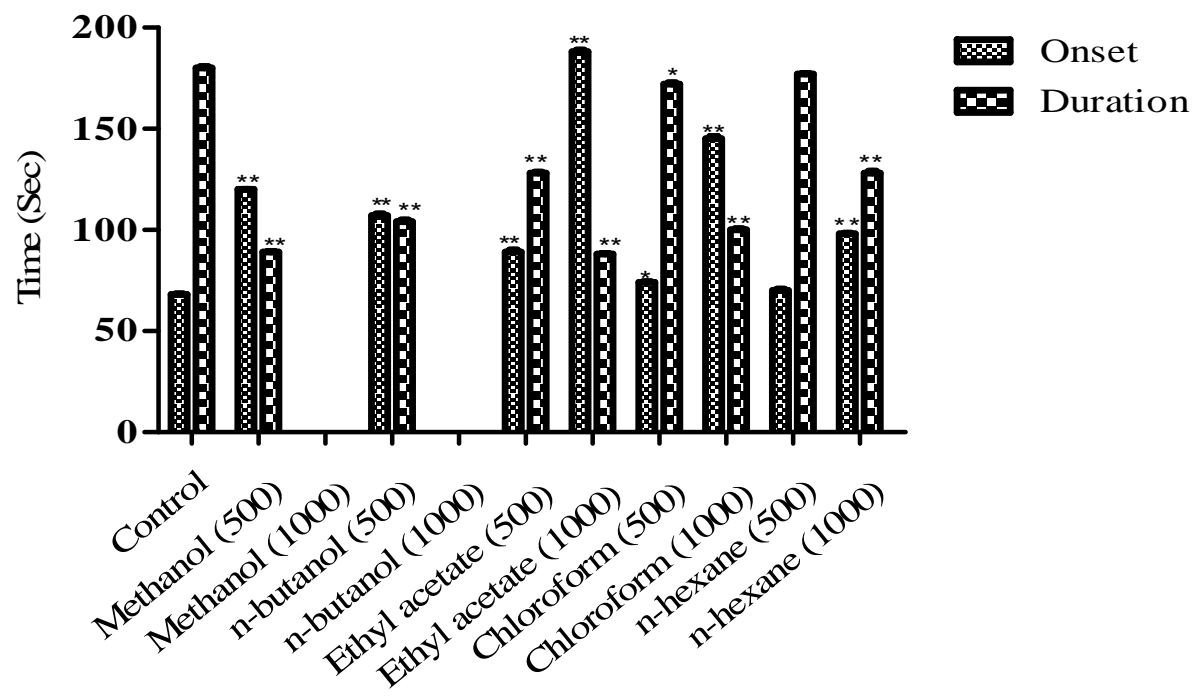

Figure 1: Anticonvulsant effect of $B$. calliobotrys extract and fractions against PTZ induced convulsions. Values are expressed as Mean \pm SEM $(\mathrm{n}=6) ;{ }^{*} p<0.05,{ }^{* *} p<0.01$ when compared with control 
The results of strychnine induced convulsions are shown in Figure 2. All the fractions and methanol extract of the plant significantly delayed the onset time and reduces the duration of convulsions except $n$-hexane fraction at the dose of $500 \mathrm{mg} / \mathrm{kg}$. However, chloroform and $\mathrm{n}$ hexane fraction provides no protection to animals against mortality.

The results of picrotoxin induced convulsions are given in Figure 3. All the fractions and methanol extract produced highly significant anticonvulsant effects against picrotoxin induced convulsions except $\mathrm{n}$-hexane fraction.

\section{Antimicrobial activity}

All the fractions and methanol extract of $B$. calliobotrys were evaluated for their antibacterial activity by disc diffusion method against $P$. aeruginosa, $S$. aureus and $B$. subtilis and their results were compared against standard antibacterial agent ciprofloxacin. An Inhibition zone of $14 \mathrm{~mm}$ was considered as significant. The methanol extract of the plant, ethyl acetate and $n$-butanol fractions showed maximum zone of inhibition against all bacterial strains especially S. aureus.

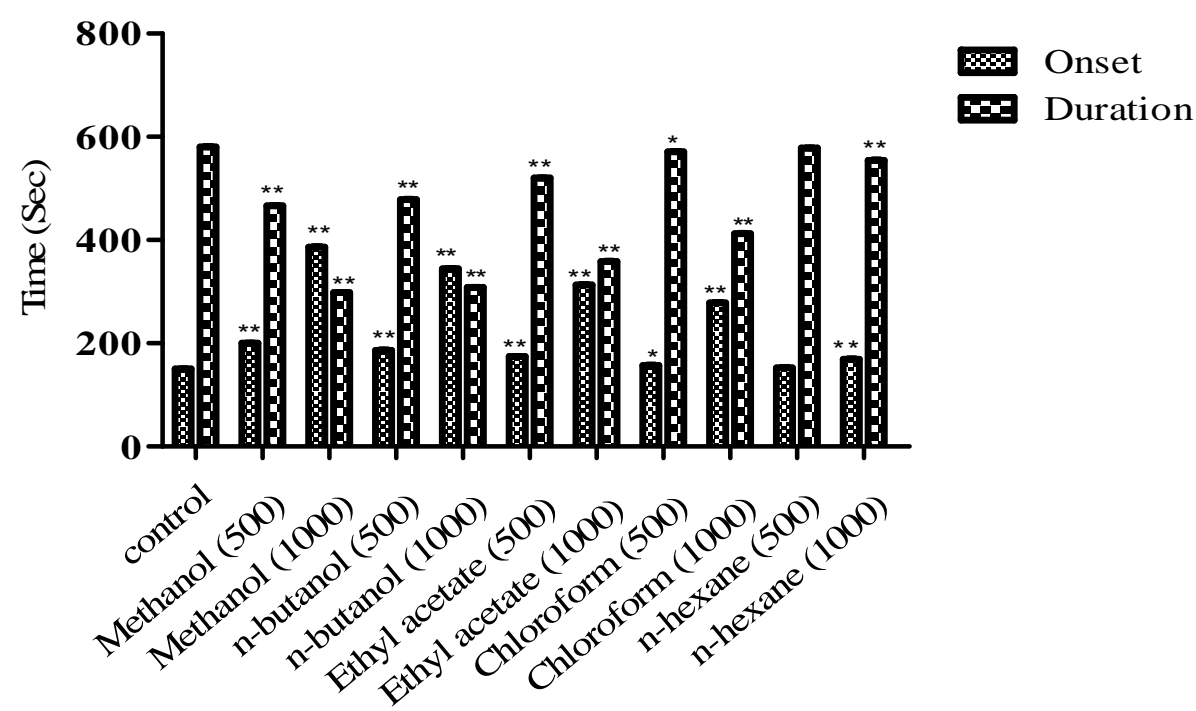

Figure 2: Anticonvulsant effect of $B$. calliobotrys extract and fractions against strychnine induced convulsions. Values are expressed as Mean $\pm \operatorname{SEM}(n=6) ;{ }^{*} p<0.05,{ }^{* *} p<0.01$ when compared with control

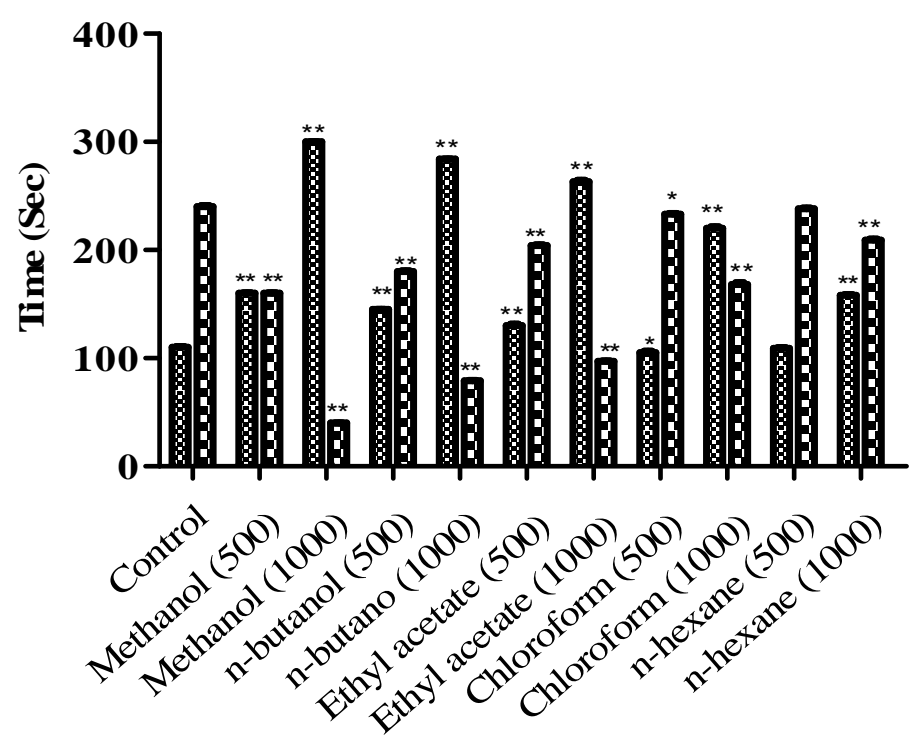

Figure 3: Anticonvulsant effect of $B$. calliobotrys extract and fractions against picrotoxin induced convulsions. Values are expressed as Mean $\pm \operatorname{SEM}(\mathrm{n}=6) ;{ }^{*} p<0.05,{ }^{* *} p<0.01$ when compared with control 
Chloroform and $\mathrm{n}$-hexane fractions, however, did not show any promising results (Table 1 ).

All the fractions of the plant showed antifungal effects when compared with the standard antifungal fluconazole, however the results were not significant with $\mathrm{n}$-hexane and chloroform fractions. The ethyl acetate, n-butanol fractions and methanolic extract significantly produced antifungal effects; however the results were not as promising as antibacterial effects (Table 1).

MIC value was also determined against bacterial and fungal strains. The methanol extract and ethyl acetate fraction showed highly significant MIC against all bacterial and fungal strains. However, n-hexane fraction did not show any significant results in the MIC assay (Table 1).

\section{In vitro cytotoxic effect}

To evaluate the cytotoxicity of the selected medicinal plant extract and its various organic fractions, the hemolytic activity method was used against human red blood cells (RBCs). The highest hemolytic effect was shown by methanol extract $(8.96 \%)$ followed by the $\mathrm{n}$ - butanol fraction $(6.32 \%)$, ethyl acetate $(4.80 \%)$, and nhexane fraction $(3.05 \%)$. Chloroform fraction showed the least hemolytic effect. However, the data obtained is in a safe range and the plant extracts and fractions may be safe for human use.

\section{HPLC data}

Ethyl acetate fraction of $B$. calliobotrys showed significant results for anticonvulsant and antimicrobial activities and so it was subjected to HPLC analysis to ascertain its phenolic content. The chromatogram is shown in Fig 4.
The phenolics (ppm) in the ethyl acetate fraction was quercitin (4.45 \pm 0.02 ), gallic acid (2.83 \pm $0.04)$, caffeic acid $(3.26 \pm 0.03)$, vanillic acid $(40.23 \pm 0.03)$, chlorogenic acid (84.44 \pm 0.06$)$, P-coumeric acid $(13.21 \pm 0.04)$ and trans-4hydroxyl, 3-methoxy cinnamic acid (3.11 \pm 0.02$)$.

\section{DISCUSSION}

Herbal drugs have gained massive importance during the last few decades and there has been an ever increasing demand for these drugs due to their various therapeutic benefits. In the current study pharmacological activities, cytotoxicity and HPLC profile of $B$. calliobotrys were evaluated.

Among many experimental models used for induction of convulsions, pentylenetetrazole (PTZ) has been most frequently employed for preliminary screening of anticonvulsant effect. PTZ produces petit mal type of epilepsy and convulsions in experimental animals by counteracting the action of inhibitory neurotransmitter GABA and thus producing hyper excitation and excessive neuronal firing, which leads to the development of epilepsy [17]. PTZ also produces convulsions by destabilizing neuronal membranes $[18,19]$. The results of the present study have clearly shown potent anticonvulsant activity of plant methanolic extract and its n-butanol and ethyl acetate fractions. The tested fractions have been found to exert anticonvulsant effect due to their potent ability to increase the time of onset of convulsions and to decrease the time of duration of convulsions caused by administration of PTZ (Figure 1). The strong anticonvulsant action of $B$. calliobotrys against PTZ-induced convulsions might be due to their action as a GABA agonist [20].

Table 1: Antimicrobial activity of methanol extract and fractions of $B$. calliobotrys

\begin{tabular}{|c|c|c|c|c|c|c|c|}
\hline \multicolumn{8}{|c|}{ Diameter of inhibition zone (mm) } \\
\hline Test microoganism & $\begin{array}{c}\text { Metha- } \\
\text { nol }\end{array}$ & $\begin{array}{c}n- \\
\text { butanol }\end{array}$ & $\begin{array}{c}\text { Ethyl- } \\
\text { acetate }\end{array}$ & $\begin{array}{c}\text { Chloro- } \\
\text { form }\end{array}$ & $\begin{array}{c}n- \\
\text { hexane }\end{array}$ & $\begin{array}{c}\text { Cipro- } \\
\text { floxacin }\end{array}$ & $\begin{array}{l}\text { Fluco- } \\
\text { nazole }\end{array}$ \\
\hline$P$. aeruginosa & $20 \pm 3$ & $20 \pm 1.52$ & $16 \pm 1.52$ & $12 \pm 2.08$ & $11 \pm 2$ & $36 \pm 20$ & \\
\hline S. aureus & $27 \pm 2.51$ & $22 \pm 2.51$ & $22 \pm 2.51$ & $18 \pm 2$ & $15 \pm 2$ & $35 \pm 10$ & \\
\hline B. subtilis & $18 \pm 1.52$ & $16 \pm 1$ & $13 \pm 1.52$ & $11 \pm 1.52$ & $9 \pm 1.52$ & $30 \pm 2.51$ & \\
\hline P. notatum & $13 \pm 1.52$ & $11 \pm 1.52$ & $13 \pm 2$ & $4 \pm 2.12$ & $3 \pm 1.52$ & & $19 \pm 1.52$ \\
\hline C. albicans & $16 \pm 1.52^{\pi}$ & $10 \pm 2.08$ & $13 \pm 2.08^{*}$ & $6 \pm 1.52$ & $3 \pm 1.52$ & & $20 \pm 1.52$ \\
\hline \multicolumn{8}{|c|}{ Minimum Inhibitory Concentration $(\mathrm{mg} / \mathrm{mL})$} \\
\hline$P$. aeruginosa & 2.06 & 2.52 & 2.32 & 2.52 & 2.80 & 0.07 & \\
\hline S. aureus & 2.05 & N.A & 2.42 & 2.35 & N.A & 0.02 & \\
\hline B. subtilis & 2.08 & 2.72 & 2.50 & 2.57 & 2.75 & 0.06 & \\
\hline P. notatum & 2.12 & N.A & 2.18 & N.A & 2.92 & & 0.10 \\
\hline C. albicans & 2.50 & 2.90 & 2.30 & N.A & N.A & & 0.01 \\
\hline
\end{tabular}

Values are expressed as Mean \pm SEM $(n=3) ;{ }^{*} p<0.05$, when compared with control; $N . A=$ no activity 


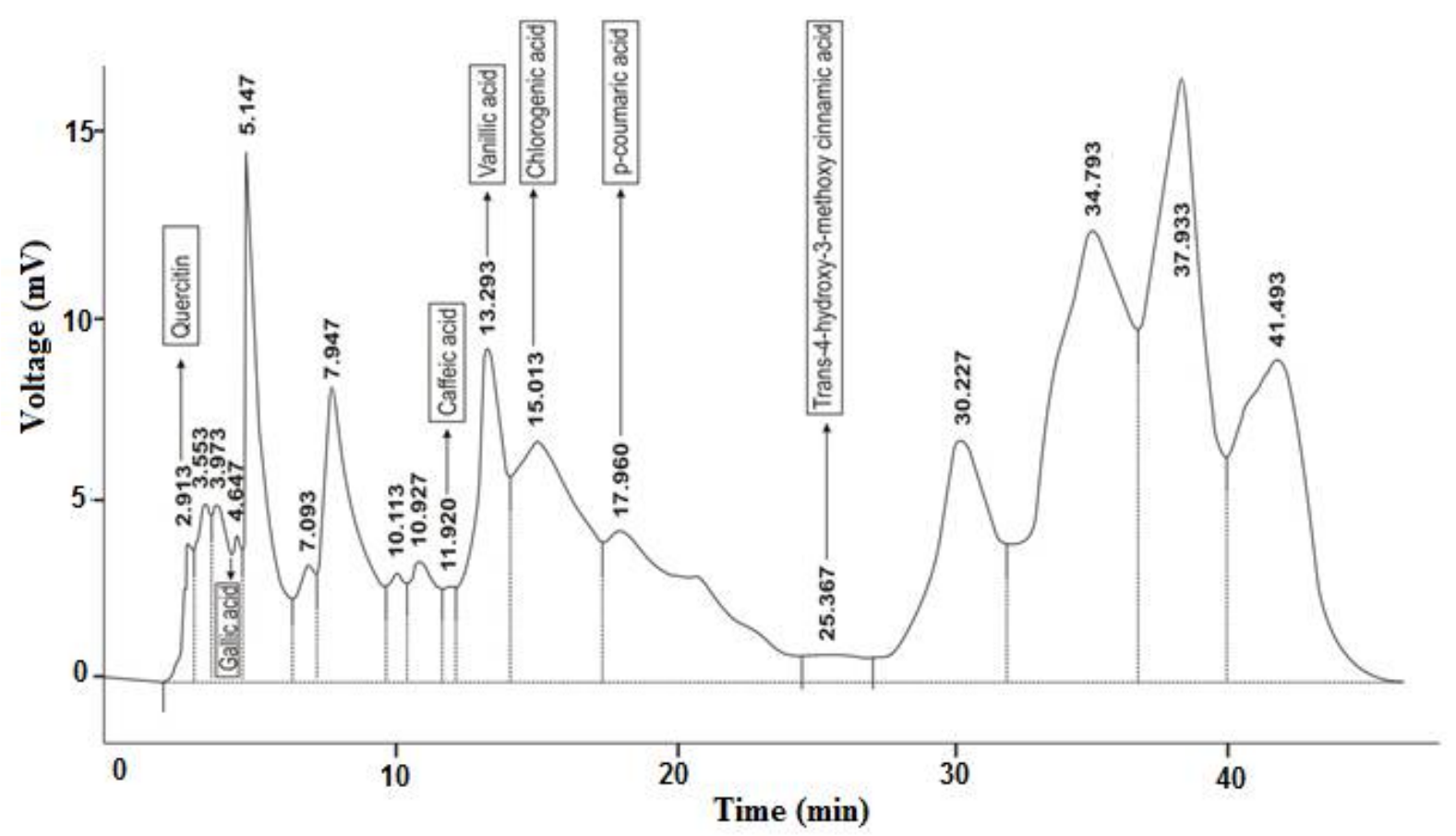

Figure 4: Chromatogram showing the phenolic profile of ethyl acetate fraction of $B$. calliobotrys

In addition, strychnine, another very potent convulsant has been shown to act on the spinal cord and produce an inhibitory effect on the inhibitory neurotransmitter glycine, which produces hyper excitability in CNS and ultimately convulsions [21]. Strychnine counteracts the action of excitatory neurotransmitters like AMPA and NMDA and it also produces inhibitory effects on calcium-induced excitotoxicity in neurons. These factors are pro-epileptogenic and precipitate seizures. So, the suppression of the inhibitory neurotransmitter, glycine leads to tonicclonic seizures in experimental animals [22]. In our study, methanolic extract, n-butanol and ethyl acetate fractions showed anticonvulsant activity against strychnine-induced convulsions in a dose-dependent manner. However, the effect was relatively more potent against PTZ-induced convulsions (Figure 2). The anticonvulsant effect of plant against strychnine-induced convulsions has indicated their ability to interfere with glycine transmission in the spinal cord.

Furthermore, picrotoxin, a non-competitive antagonist at GABA receptors, has been reported to block the GABA-activated chloride ionophore [23]. Methanolic extract, n-butanol and ethyl acetate fraction have also demonstrated anticonvulsant activity against picrotoxin induced convulsions (Figure 3). This also indicated that the plant extract and its various fractions exert their anticonvulsant effect due to modification of function of GABA receptor-mediated chloride channels. The results of different studies have provided evidence that some medicinal plants do possess antimicrobial activities and may act as a potential source of new antibacterial agents even against some antibiotic-resistant strains [24]. In the present study conducted by using the disc diffusion method, it has been observed that the extract and fractions of plant possessed significant antibacterial activity against certain gram negative ( $P$. aeruginosa) and gram positive (S. aureus, B. subtilis) pathogens, i.e. bacteria. The results of this study were in agreement with the earlier studies [25-27].

Antimicrobial activity of the methanolic extract and fractions of $B$. calliobotrys have also exposed noticeable difference in sensitivity against pathogenic fungi $P$. notatum and $C$. albicans. The variation in the effectiveness of the extracts against different microorganisms would be due to differences in the chemical composition of the extracts. In the disc diffusion technique lessening in microbial growth is determined on the basis of zone of inhibition around the disc. An inhibition zone of $14 \mathrm{~mm}$ or more has been reckoned to be a significant antimicrobial activity [28]. In our study high antimicrobial activity, i.e. (inhibition zone of 14 $\mathrm{mm}$ ) was produced by some fractions of the plant.

The minimum inhibitory concentration (MIC) results showed that methanol extract and ethyl acetate fraction had highly significant MIC against all bacterial and fungal strains. The least 
MIC value exhibited that less concentration was required to inhibit the selected bacterial and fungal strains. The higher MIC represented that the tested samples had less antimicrobial activity.

The differences in anticonvulsant and antimicrobial activities of plant extract and its various fractions were possibly due to different concentration of their constituents. The phytochemicals are produced in many plant species and exhibit pharmacological and biological activities. Antioxidant and antimicrobial activities were reported in various plants due to the presence of tannins, alkaloids, steroids, saponins and phenolic compounds [28,29]. Terpenoids are found in various plant parts having many therapeutic uses like antimicrobials and also used in many pharmaceutical preparations [30]. The analyzed phytoconstituents in this study might be responsible for their pharmacological actions. Ethyl acetate fraction exhibited very promising pharmacological effects, i.e. Anticonvulsant and antimicrobial. So, the phenolic constituents present in this fraction were estimated by HPLC which might be responsible for these actions. The earlier reports showed that the phenolic compounds present in various plant extracts play a vital role for their antimicrobial and other activities [31].

The mechanical stability of the red blood cell membrane is essential to reduce the cytotoxic effects of different compounds. The least in vitro cytotoxicity of different plant extracts is of great importance for their safe use in different diseases other than cancer [32]. In the present research all the samples tested for in vitro hemolytic activity were found in a safe range i.e. below $10.0 \%$, so it could be expected that the methanol extract and is various organic fractions have a minor cytotoxicity [33]. The plant extracts or fractions having minor cytotoxicity might be used as herbal medicines [34].

\section{CONCLUSION}

The findings of this study indicate that the crude methanol extract and its organic fractions of $B$. calliobotrys possess strong anticonvulsant and antimicrobial effect. The plant is thus a potential source of new lead compounds for the development of new clinically effective anticonvulsant and antimicrobial compounds.

\section{REFERENCES}

1. Ali SI., Nasir E. Flora of Pakistan. Department of Botany, University of Karachi: Karachi; 1989; pp 1-145.
2. Ali H, Qaiser M. The ethnobotany of Chitral valley, Pakistan with particular reference to medicinal plants. Pak J Bot 2009; 41: 2009-2041.

3. Fazal S, Tariq $M$, Shamim $M$. Khyberine and the biogenesis of dimeric aporphine-benzylisqoquinoline alkaloids. Tetrahed Lett 1980; 21: 4573-4576.

4. Kametani T, Honda T. Aporphine alkaloids. Alkal Chem Pharmacol 1985; 24: 153-251.

5. Brain KR, Turner $K R$. The practical evaluation of phytopharmaceuticals. Wright- Scientehnica, Bristol, UK; 1975; pp 187-189.

6. NIH. National Research Council Guide for the Care and Use of Laboratory Animals. NIH Washington, DC. 1985; 23: 85.

7. Edeoga HO, Okwu DE, Mbaebie BO. Phytochemical constituents of some Nigerian medicinal plants. Afri J Biotech 2005; 4: 685-688.

8. Kokate CK.; Purohit AP.; Gokhale SB. Pathway to screen phytochemical nature of natural drugs. In: Pharmacognosy 39th Ed. NiraliPrakashan: Abhyudaya, India; 2007. p. 607-611.

9. United States Pharmacopoeia. 28th Ed. The United States Pharmacopeial Convention: U.S.A; 2012; pp 864-869.

10. Swinyard EA, Woodhead JH, White HS, Franklin MR. General Principles: Experimental selection, quantification and evaluation of anticonvulsants. In: Levy R.; Mattson R, Meldrum B, Penry JK, Dreifuss FE. Antiepileptic Drugs, Raven Press: New York; 1989; pp 85-103.

11. Ergene A, Guler P, Tan S, Mirci S, Hamzaoglu E. Antimicrobial and antifungal activity of Heracleums phondylium subsp. artivinense. Afr J Biotech 2006; 5 (11): 1087.

12. Nishanta R, Cory S, Harris, Towers GHN. Antimicrobial activity of plants collected from serpentine outcrops in SriLanka. Pharm Biol 2002; 40 (3): 235-244.

13. Sarker SD, Nahar L, Kumarasamy Y. Microtitre platebased antibacterial assay incorporating resazurin as an indicator of cell growth, and its application in the in vitro antibacterial screening of phytochemicals. Methods 2007; 42 (4): 321-324.

14. Sharma $P$, Sharma JD. In vitro hemolysis of human erythrocytes by plant extracts with antiplasmodial activity. J of Ethno pharma 2001; 74: 239-243.

15. Aslam F, Rasool N, Riaz M, Zubair M, Rizwan K, Abbas $M$, Bukhari TH, Bukhari $I H$. Antioxidant, haemolytic activities and GC-MS profiling of Carissa carandas. Int $J$ of Phyto Med 2011; 3: 567-578.

16. Sultana B, Anwar F, Przybylyski R. Antioxidant activity of phenolic components present in barks of Azadirachta indica, Terminalia arjuna, Acacia nilotica and Eugenia jambolana Lam. Trees. Food Chem 2007; 104: 11061114.

17. Ha JH, Lee DU, Lee JT, Kim JS, Yong CS, Kim JA. 4Hydroxybenzaldehyde from Gastrodiaelata as active in the antioxidation and GABAergic neuro modulation

Trop J Pharm Res, November 2015; 14(11): 2038 
of the rat brain. $J$ Ethnopharmacol 2004; 73: 3 29333.

18. Curtis DR, Duggan AW, Felix D, Johnston GAR, McLennan $H$. Antagonism between bicculline and GABA in the cat brain. Brain Res 1971; 33: 57-73.

19. Gnyther $B D$, Curtis $D R$. Pyridazinyl GABA derivatives as $G A B A$ and Glycineantagonist in the spinal cord of the cat. Neurosci Lett 1986; 68: 585-587.

20. Bum EN, Schmutz M, Meyer C, Rakotonirina A, Bopelet $M$, Porter C. Anticonvulsant properties of the methanolic extract of Cyperus articulates. $J$ Ethnopharmacol 2001; 76:145-150.

21. Adeyemi OO, Akindele AJ, Yemitan OK, Fagbo FI. Anticonvulsant, anxiolytic and sedative activities of the aqueous root extract of Securida calonge and pendunculata fresen. $J$ Ethanopharmacol 2010; 130 : 191-195.

22. Rogawski MA. Revisiting AMPA receptors as an antiepileptic drug target. Epilepsy Curr 2011; 11: 56 63.

23. Vogel HG, Vogel WH. Drug discovery and evaluation, pharmacological assay. Berlin Springer; 1997; pp 260-261.

24. Kone WM, Atindehou C, Terreaux K, Hostettmann D, Traore, Dosso M. Traditional medicine in North Coted'lvoire: screening of 50 medicinal plants for antibacterial activity. J Ethnopharmacol 2004; 93: 4349.

25. Fan $M$, Chen J. Studies on antimicrobial activity of extracts from thyme. Wei Sheng Wu Xue Bao 2001; 41: 499-504.
26. Yuste J, Fung DY. Inactivation of Salmonella typhimurium and Escherichia coli O157: H7 in apple juice by a combination of nisin and cinnamon. J. Food Prot 2004; 67: 371-317.

27. Olayemi MA, Oluwasola OO. Effect of light irradiation on the antimicrobial activity of Zanthoxylum zanthoxyloides (lam) methanolic extract. Afr $\mathrm{J}$ Pharmacol 2010; 4 (4): 145-150.

28. Riaz M, Rasool N, Bukhari IH, Shahid M, Zubair M, Rizwan K, Rashid U. In vitro antimicrobial, antioxidant, cytotoxicity and GC-MS analysis of Mazus goodenifolius. Molecules 2012; 17: 1427514287.

29. Erol NT, Sarı F, Velioglu YS. Polyphenols, alkaloids and antioxidant activity of different grades of turkish black tea. GIDA J Food 2010; 35: 161-168.

30. Michael, S.A. Life of its own. The New Yorker, New York: USA; 2009. 1-50 p.

31. Mori A, Nishino C, Enoki N, Tawata S. Antibacterial activity and mode of action of plant flavonoids against Proteus vulgaris and Staphylococcus aureus. Phytochem, 1987; 26: 2231-2234.

32. Uddin SJ, Grice ID, Tiralongo E. Cytotoxic effects of Bangladeshi medicinal plant extracts. Evid Base Compl and Alter Medi 2011; 1-7.

33. Sharma $P$, Sharma JD. In vitro hemolysis of human erythrocytes by plant extracts with antiplasmodial activity. J Ethnopharmacol 2001; 74: 239-243.

34. Aslam F, Rasool N, Riaz M, Zubair M, Rizwan K, Abbas $M$, Bukhari TH, Bukhari $I H$. Antioxidant, haemolytic activities and GC-MS profiling of Carissa carandas. Int J Phytomedi 2011; 3: 567-578. 